\title{
Non-verbal communication of English speaking skills in single-sex classroom management
}

\author{
Hardianti Lestari Hamsah \\ Universitas Negeri Makassar, Makassar, 90221, Indonesia \\ e-mail: hardianti@darulaman.sch.id
}

\begin{abstract}
This research explores to what extent the eleventh year's students of the single-sex classroom management have mastered the English speaking skills regarding eye contact, enthusiasm, and confidence. This research exposes to what extent the eleventh year's students of the single-sex classroom management have mastered the English speaking skills regarding eye contact, enthusiasm, and confidence. This study used a qualitative method by descriptive design. The procedure of collecting data the researcher used classroom observation, teacher interview, and student' focus discussion group. In collecting data and analysis technique the researcher measured from three aspects namely students 'confidence, eye contact, and enthusiasm. Each aspect was described. This study revealed that the female students who have already been in the single-sex classroom have high confidence, convey strong enthusiasm and maintain eye contact well while speaking English. Therefore, we can say that the eleventh year's students of the single-sex classroom management have mastered the English speaking skills regarding eye contact, enthusiasm, and confidence in which the researcher in a single-sex classroom has done the criteria.
\end{abstract}

\section{Keywords:}

Nonverbal communication; English speaking skills; single-sex classroom, classroom management

\section{INTRODUCTION}

Many studies have been conducted on the use of strategies, approaches, techniques, or media, in improving English speaking skill. Demers and Bennett (2007), the researcher from Literacy and Numeracy Secretariat and the Ontario Associations of Deans Education which discussed issues on single-sex educational types concludes that the strength of this work is that single-sex education is one of a new paradigm which creates successful learning. In other words, the work shows that researching single-sex classroom in some private and public schools in the US and Canada got positive impact in succeeding the students' achievement. Meanwhile, the weakness of this type of education is only one of a short-term solution. This approach might only help the students achievement for a moment, not for an extended period and its effect might be better for female students only. However, this research focuses on the singlesex effect to improve speaking skill. The work is focused on writing and reading, while this research is on speaking skill.

Smyth (2010) found that single-sex school is sufficient for both males and females achievement. Male students are more likely to study a female subject in a single-sex classroom. As a result, they achieve better in that type of class. 
Moreover, this truth is for female students, but the weakness of this type of education is the adverse effect regarding personal and social development. It means that the students of the single-sex classroom will be disturbed in their development because they do not usually interact with another gender which is sometimes needed to succeed in their social development. The last is the gap. Some researchers had no focus on the particular subject or specific skill of subject. Kylberg and Wulff (2009) stated that single-sex classroom is only influenced paramount for female students since they acquired the chance to improve their performance deprived of bothered by loud male students. Moreover, this kind of school is needed to have both male and female workers outcome. The school applies coeducational classroom which involves both sexes in the teaching-learning process and might them interact with each other to maintain social relations. Moreover, the gap is single-sex applied in reading class as a sample to research.

Morse (1998) conduct the research related to the single-sex law with some considerations., US schools permitted to have innovative programs in order to succeed the learning process, and finally, the single-sex classroom might be created in elementary and secondary schools to give balance chance for the pupils in getting knowledge and reaching a better position in their next future. There is no focus here that single-sex class is applied to what subject, therefore, the researcher deliberates that this type of education is used in complete school activities but only in one school levels. Thompson and Ungerleider (2004) concern on single-sex school also ever held in Canada. One of school there found the strength of this type of classroom; female students feel better in the single-sex classroom because of they likely to get burden from male students which influence their learning process. With this reality makes female students more interest in studying and it is true that it influences their achievement. However, this single-sex classroom disturbs the students ${ }^{e e}$ psychology and social relationship. This research compared both coed and single-sex schools with the aim of knowing for each positive and negative side to be implemented in the future education.

Trickett et al. (1982) compared students' achievement between a singlesex and coed classroom in Woodward Avenue Elementary School. After getting the same treatment with the same condition and teachers ${ }^{\text {ee }}$ training, they are tested to get the achievement differences. As a result, female students achieve better in the coed classroom and on the contrary, male students achieve better in a single-sex classroom. However, when they have interviewed, female students prefer to have single-sex with reason leaving the male students intimidation, while male students choose coed classroom because they feel more comfortable with that. In this work, the researcher did not focus on the particular subject. Jackson (2002) study is related to school types conducted in England shows that government program to give an equal chance for female and male students by giving them a different place to learn, it means that in a different school or a school which has been divided. The fact shows that there are no differences between their achievement because not all male students are active and dominate the class and so for female students. While, the focus of 
this research is all subjects in the school, include feminine and masculine subject to get stronger differences but in fact, there is no difference at all.

Doris, O'Neill, and Sweetman (2013) examine the determinants of mathematical achievement among primary school children. The differences in the size of the maths gap across countries may be explained by differences in the prevalence of single-sex schooling. If anything, the gender differential is more extensive for children educated in single-sex schools than in coeducational schools. These findings are not affected by the inclusion of a proxy for early childhood ability or by the use of instrumental variables to control for potentially endogenous school choice. Hughes (2006) explored whether public schools should afford a choice for parents to have single-sex education using coeducation. The researcher has confidence in single-sex classrooms or singlesex schools student achievement would be in positive impact. Moreover, in single-sex classes or single-sex schools, student behaviors will improve, students in poverty or minority students would benefit, and students' learning style differences would be better.

Malik (2013) studied the fourteen personality traits on the Children Personality Questionnaire showed boys and girls in the single-sex schools as more outgoing and participative, enthusiastic and livelily, conscientious and rule-bound, socially bold and spontaneous, individualistic, self-reliant and realistic, shrewd and sharp, untroubled and self-assured, self-disciplined and socially-précised, relaxed and un-frustrated. On the other hand, boys and girls in the coeducational schools were found more reserved and cool and serious, expedient and disregarding rules, timid and shy, dependent and sensitive, vigorous and group dependent, naïve and sentimental, worried and depressed, casual and careless of social rules, tense and frustrated. Pahlke, Hyde, and Allison (2014) focused on the effects of single-sex compared with coeducational school in a wide array of variables, including mathematics performance and attitudes, science and verbal performance, gender stereotyping, self-concept, and interpersonal relations. In all, the analyses were based on the results of 184 studies and 1,663,662 students.

Based on the finding theories of ELT practitioners, the researcher decided to research examining the nonverbal components of English speaking skill of single-sex classroom management of students in SMA IT Wahdah Islamiyah Makassar, Makassar, Indonesia. This school places female and male in a different class for Islamic religion rules reason (Patak, Nur, Said, \& Yaumi, 2014). By conducting single-sex classroom management, female students will be comforting to develop their English Speaking Skills especially in nonverbal skills, such as Eye contact, Enthusiasm, and Confidence. Therefore, the researcher would like to unsolved the fact of nonverbal components of English speaking skills whether single-sex classroom management of the eleventh year's students of SMA IT Wahdah Islamiyah Makassar, Makassar, Indonesia. In addition, the previous studies showed that many ways could help the students to master their speaking ability, meanwhile both of their research was to improve the students' speaking only in accuracy by applying some methods or techniques, strategy no one researchers classified their research to the developing of students' speaking skill especially for their confidence, eye 
contact, and enthusiasm. In this research, the researcher analyzed three items of nonverbal components of English speaking skill such as confidence, eye contact, and enthusiasm in female student class that applying single-sex classroom.

\section{RESEARCH METHOD}

In this research, Issues to be studied is dynamic. It is determined by the nonverbal of English speaking skills in the single-sex classroom management at the eleventh years of high school students IT Wahdah Islamiyah Makassar, Makassar, Indonesia. Therefore, the researchers choose to use qualitative research methods. This study used a qualitative method by descriptive design. According to Creswell and Creswell (2017) that qualitative research is an analysis process of understanding based on different procedural conducts of inquiry that discover social or human issues. The researcher builds a complex, holistic picture, analyzes words, reporting detailed views of information, and conducts the study in a natural setting. The qualitative research was used to investigate the nonverbal of English speaking skills in the single-sex classroom management of students. The case study used to seek a collection of instances from the data in the hope of the issue that happened in this research. The method carefully illustrates the individual or specific group of circumstances and symptoms that occur. The researcher would employ the method through 3 steps.

\subsection{Classroom Observation}

Observation is used in gathering information using observation involves watching or listening to events, then recording what occurred (Thomas, 2003). Observation can be either direct or mediated. This is a kind of directed observation when the researcher sees and hears the ongoing activities of the students in the classroom directly. According to Creswell and Creswell (2017) that there are several steps to conduct an observation:

- Select a site to be observed

- At the site, identify who or what to observe

- Determine, initially, a role as an observer.

- Design an observational protocol as a method for recording notes in the field.

- Records aspects such as portraits of the informant, the physical setting, particular events and activities, and reactions

- During the observation, have some introduction. If an outsider, be passive and friendly as well as start with limited objectives in the first few sessions of observation.

- After observing, withdraw slowly from the site, thanking the participants and informing the participants of data usage and their accessibility to the study.

From this observation, I captured the real situation of students in the classroom. How their confidence, enthusiasm and eye contact in speaking 
English during the learning process. While observing the classes, I tried to note down the students' English speaking skills regarding enthusiasm, eye contact, and confidence in general. The actual number of students is 28 . However, the observation sheet has been included with the appendix page. This observation will carry out to obtain the real events of students in the classroom to answer the research question to what extent students in the single-sex classroom have mastered in nonverbal English speaking skill. With the result, after doing this observation, the researcher will find out the extent of students in single-sex classroom management has mastered nonverbal English speaking skills.

\subsection{Interview}

Interview means usually involve a researcher orally asking questions for individuals to answer orally. Interviews traditionally have been conducted face to face and one to one, with the researcher speaking directly with one interviewee at the time. This study used the traditional one and semi-structured design (when the interviewer can ask additional questions when it is needed).

According to Creswell and Creswell (2017) that there are several steps to conduct an interview:

- Identify interviewees by one of the purposeful sampling procedures mentioned in the preceding.

- Determine the possible interview type and the most useful information to answer the research questions.

- Whether conducting a one-to-one interview, I recommend using an adequate recording procedure, such as tape.

- Design the interview protocol, a form about four or five passages in length. With approximately five open-ended questions and sample space between the questions to write responses to the interviewee's comments.

- Determine the place for conducting the interview.

- After arriving in the interview site, obtain consent from the interviewee to participate in the study.

- During the interview, stick to the questions, complete within the time specified (if possible), be respectful and courteous, and offer few questions and advice.

This is a teacher interview. The number of teachers' interview I will take is one. She is an English teacher. I will ask the deep questions about the singlesex classroom and nonverbal English speaking skills of students. The total number of the focused questions for the interview was 12 questions. However, I tried to maintain a conversational environment from where I had mixed the preset questions and latter filtered the required information. From this interview, the researcher will acquire to gain the deep information from the teacher about the extent of students in the single-sex classroom management have mastered nonverbal English speaking skills. So that, data from this interview will contribute deep and more information, especially from the 
teacher's view. It will also help the researcher in proving information from another technique of data collection.

\subsection{Focus Discussion Group}

This focus group discussion is small group interviewing of ten students led through an open discussion by a skilled moderator in a loosely structured discussion of English speaking skill topics. Ideally, the focus group discussion is conducted by a team consisting of moderator and assistant moderator. In this focus group discussion, my friend will be as the moderator who facilitates the discussion by giving some questions to discuss, and I will be as the assistant who takes notes of nonverbal of English speaking skill of students and runs the tape recorder. The moderator supports expose in an exposed and thoughtless arrangement. The moderator generates a maximum number of different ideas and opinions from as many different students in the time allotted. The model amount of time to set aside for a focus group is anywhere from 45 minutes. Focus groups are structured about a set of wisely determined questions - there are 11 - but the discussion is free-flowing. Participant comments will stimulate and influence the thinking and sharing of others. Some students even find themselves changing their thoughts and opinions during the group.

This research takes more than one focus group discussions. The researcher chooses ten students randomly. Afterward, they will divide into two sections. The first section includes five students and the second section also include five students. During the process of focus group discussion, directly the assistant moderator (researcher) will gain the confidence, eye contact, and enthusiasm of students in English speaking. However, the concentration was also on to drag the answers of the preselected questions. The numbers of those questions were 12 .

The researcher chooses to conduct this focus group discussion to avoid the perception of the researcher only. With conduct this focus group discussion, the information or data would be more objectives and original. Furthermore, Focus group discussion can reveal a wealth of comprehensive information and profound insight. Focus group creates a tolerant setting that makes participants relax by allowing them to thoughtfully response questions in their own words and add meaning to their answers. Besides, the research question is to what extent the students in the single-sex classroom have mastered in English speaking skills regarding eye contact, enthusiasm, confidence and focus groups are well suited for those situations.

\section{RESULT AND DISCUSSIONS}

\subsection{Eye contact}

The result of the first, the second and the third classroom observations showed that the 28 students maintained eye contact in three specific degrees. The first classroom observation, 13 students maintained eye contact when they spoke English with their friends virtually all the time, 8 of the students maintained eye contact when they speak English with their friends less than $75 \%$, and 7 of the students maintained eye contact when they speak English with their friends less than $50 \%$. There were not students that avoid eye contact when they speak 
English with their friends. The second classroom observation, 11 of the students maintained eye contact when they speak English with their friends virtually all the time, 9 of the students maintained eye contact when they speak English with their friends less than $75 \%$ and 8 of the students maintained eye contact when they speak English with their friends less than 50\%. There were not students that avoid eye contact when they speak English with their friends. The third observation, 11 of the students maintained eye contact when they speak English with their friends virtually all the time, 9 of the students maintained eye contact when they speak English with their friends less than $75 \%$ and 8 of the students maintained eye contact when they speak English with their friends less than $50 \%$. There were not students that avoid eye contact when they speak English with their friends.

Furthermore, the result of teacher interview showed that students could maintain their eye contact. According to NY statements in answering the question number 7, about eye contact of students in the classroom. NY informant said that:

"In English speaking skill, for example in doing debate, I see my students have maintained their eye contact well, they tried to maintain their eye contact and how their speaking would be accepted to the audience or delivered with the listener. (Int, February 11, 2015)

Also, the result of focus group discussion section I showed that the students need to maintain their eye contact while speaking English. Students said that:

"Yes, we need." (FGD I, A5 March 6, 2015)

"It will increase our confidence." (FGD I, A4 March 6, 2015)

"Eye contact is significant." (FGD I, A3 March 6, 2015)

"It will become a mark that the audience receives the speaker messages." (FGD I, A1 March 6, 2015)

The students also described their eye contact while speaking English. They said that:

"I look at the eye's audients." (FGD I, A4 March 6, 2015)

"I look at the roof." (FGD I, A3 March 6, 2015)

"I look the everywhere." (FGD I, A1 March 6, 2015)

"I look at the wall or floor." (FGD I, A5 March 6, 2015)

The students who conducted the second section of focus group discussion also add another reason about the function of eye contact for them. The students said that:

"Yes, we used." (FGD 2, A2 March 6, 2015)

"Very important because I can tell the message to them." (FGD 2, A4 March 6, 2015)

"To make the audients focus on the speaker." (FGD 2, A5 March 6, 2015)

"Make audients pay attention to me." (FGD 2, A1 March 6, 2015)

The students from the second section of the focus group discussion also described their eye contact while speaking English. The students said that:

"I see eyes of my friend." (FGD 2, A5 March 6, 2015)

"Sometimes the wall." (FGD 2, A1 March 6, 2015)

"Sometimes the floor." (FGD 2, A4 March 6, 2015)

Based on the study of notes of student's skill in doing focus group discussion, the researcher found that students who conduct the first section of focus group discussion, three students of them maintained eye contact and 
focused on moderator without looked anywhere, and two of them did not focus and just used her phone. In the other side, the researcher found that students who conduct the second section of focus group discussion, all of them maintained eye contact and her eyes focus on the moderator.

\subsection{Confidence}

The result of the first, the second and the third classroom observations showed that the 28 students confidence in three specific degrees. The first classroom observation showed that 16 of the students spoke neither too quickly nor too slowly, 7 of the students spoke either slightly too quickly or too slowly, and 5 of the students spoke too quickly or too slowly. There were not students that spoke inappropriate tempo. The second classroom observation, showed that 11 of the students maintained eye contact when they speak English with their friends virtually all the time, 9 of the students maintained eye contact when they speak English with their friends less than $75 \%$, and 8 of the students maintained eye contact when they speak English with their friends less than $50 \%$. There were not students that avoid eye contact when they speak English with their friends. Moreover, the third classroom observation showed that 13 of the students spoke neither too quickly nor too slowly, 7 of the students spoke either slightly too quickly or too slowly, and 6 of the students spoke too quickly or too slowly. Two students spoke inappropriate tempo.

Furthermore, the result of teacher interview showed that students' confidence is very high. According to NY statements in answering the question number 8 , about the confidence of students in the classroom. NY informant said that:

"When I ordered them to perform in front of the class to speak English, most of them have high confidence, and they did not feel shy or afraid. However, there was a student who has low confidence, but she still tries to make the best efforts, and another student in the class got her motivations". (Int, February 11, 2015)

Also, the result of focus group discussion section I showed that the students are feeling in the single-sex classroom while they speak English. Students said that:

"Yes, we are very comfortable with that." (FGD I, A5 March 6, 2015)

"Because there are no boys in the class." (FGD I, A4 March 6, 2015

"If there were a boy, I will forget the word that I want to say." (FGD I, A3 March 6, 2015)

"Boys just make us trembling, nervous." (FGD I, A1 March 6, 2015)

"And we do not know what we should do." (FGD I, A2 March 6, 2015)

The students also described their confidence while speaking English. They said that:

"Sometimes feel shy." (FGD 1, A2 March 6, 2015)

"I am not shy." (FGD 1, A5 March 6, 2015)

"There is no reason to shy." (FGD I, A4 March 6, 2015)

"Don't care, just speaking." (FGD I, A3 March 6, 2015)

"Because there are students female only in class" (FGD I, A1 March 6, 2015)

The students also stated that:

"Yes." (FGD 1, A2 March 6, 2015)

"Maybe." (FGD 1, A5 March 6, 2015)

"We are very confident." (FGD I, A4 March 6, 2015) 
"Because our class just have one gender, so she did not feel shy each other." (FGD I, A3 March 6, 2015)

"Yes, very confidence" (FGD I, A1 March 6, 2015)

The students who conducted the second section of the focus group discussion also add another reason for their confidence in the single-sex classroom. The students said that:

"Yes, we are very comfortable with that." (FGD 2, A1 March 6, 2015)

"Because there are no boys in the class." (FGD 2, A3 March 6, 2015)

"If there were a boy, I will forget the word that I want to say." (FGD 2, A4 March 6, 2015)

"Boys just make us trembling, nervous." (FGD 2, A5 March 6, 2015)

"And we do not know what we should do." (FGD 2, A2 March 6, 2015)

About the students' shy. They stated that:

"Sometimes." (FGD 2, A2 March 6, 2015)

"I am not." (FGD 2, A3 March 6, 2015)

"There is no reason to shy." (FGD 2, A4 March 6, 2015)

"Don't care, just speaking." (FGD 2, A5 March 6, 2015)

"Because there are students female only in class" (FGD 2, A1 March 6, 2015)

The students from the second section of the focus group discussion also described their eye contact while speaking English. The students said that:

"Yes." (FGD 2, A3 March 6, 2015)

"Yes, very confidence" (FGD 2, A4 March 6, 2015)

"We are very confident" (FGD 2, A1 March 6, 2015)

"Maybe" (FGD 2, A2 March 6, 2015)

"Because our class just have one gender, so we did not feel shy each other (FGD 2, A5 March 6, 2015)

Based on the study of notes of student's skill in doing focus group discussion, the researcher found that students who conduct the first section of the focus group discussion, the students were enjoyed in doing FGD. They did not feel bored and shy. They answered the question. In the other side, the researcher found that students who conduct the second section of focus group discussion, they were delighted and much enjoyed in doing FGD.

\subsection{Enthusiasm}

The result of the first, the second and the third classroom observations showed that the 28 students' enthusiasm in three specific degrees. The first classroom observation, showed that 17 of the students used body language (move their hands, tapping fingers) and facial expression (smiling, showing happy, anger, sad, etc.) convey strong enthusiasm and interest, 9 of the students used body language ( move their hands, tapping fingers, etc.) and facial expression (smiling, showing happy, anger, sad) sometimes strong enthusiasm and interest, 4 of the students used body language ( move their hands, tapping fingers) and facial expression (smiling, showing happy, anger, sad) seem contrived. There were not students that apparent disinterest. The second classroom observation, showed that 16 of the students used body language (move their hands, tapping fingers) and facial expression (smiling, showing happy, anger, sad) convey strong enthusiasm and interest, 10 of the students used body language ( move their hands, tapping fingers) and facial expression (smiling, showing happy, anger, sad) sometimes strong enthusiasm and interest, 2 of the students used body language ( move their hands, tapping 
fingers) and facial expression (smiling, showing happy, anger, sad) seem contrived. There were not students that apparent disinterest. The second classroom observation, showed that 16 of the students used body language ( move their hands, tapping fingers) and facial expression (smiling, showing happy, anger, sad) convey strong enthusiasm and interest, 10 of the students used body language ( move their hands, tapping fingers) and facial expression (smiling, showing happy, anger, sad) sometimes strong enthusiasm and interest, 2 of the students used body language ( move their hands, tapping fingers) and facial expression (smiling, showing happy, anger, sad) seem contrived. There were not students that apparent disinterest.

Furthermore, the result of teacher interview showed that students' enthusiasm conveys strong. According to NY statements in answering the question number 9, about the confidence of students in the classroom. NY informant said that:

"Student in class is very spirit if they learn to speak English. They awarded that English is essential and their environment where has female students only support them to be more interest and spirit speak English". (Int, February 11, 2015)

Also, the result of focus group discussion section I showed that the student's enthusiasm in the single-sex classroom during they speak English. Students said that:

"Yes, we are very interested." (FGD I, A5 March 6, 2015)

"Why, Be like English." (FGD I, A4 March 6, 2015

"We do not feel shy to use it in front of the class." (FGD I, A3 March 6, 2015)

The students also described their enthusiasm while speaking English. They said that:

"Yes, we like." (FGD I, A4 March 6, 2015)

"Sometimes we combine in Korea language." (FGD I, A3 March 6, 2015)

"Although our speaking rather unclear" (FGD I, Al March 6, 2015)

The students who conducted the second section of focus group discussion also add another reason for their enthusiasm in the single-sex classroom. The students said that:

"I am very interest." (FGD 2, Al March 6, 2015)

"It is one way to appreciate our self." (FGD 2, A4 March 6, 2015)

"It is a challenging one. To practice our skill in grammar by speaking (FGD 2, A5

March 6, 2015)

"Yes." (FGD 2, A2 March 6, 2015)

About the students' interest. They stated that:

"Yes." (FGD 2, A2 March 6, 2015)

"Very like." (FGD 2, A3 March 6, 2015)

"Because speaking will motivate me to add vocabulary." (FGD 2, A4 March 6, 2015)

Based on the study of notes of students' skill in doing focus group discussion, the researcher found that students who conduct the first section of the focus group discussion were a very spirit to answer some questions. They answered the questions by good smiling and excellent intonation. They also used her hands and her face to explain her answer.

In the other side, the researcher found that students who conduct the second section of focus group discussion were the same with students in the first focus 
group discussion. They were delighted, and much enjoyed doing FGD. Based on the study above the female students which have already been in the singlesex classroom, have high confidence, convey strong enthusiasm and maintain eye contact well. The classroom condition which homogenous with all students are female influence them become freer to speak up in English and more enjoy learning to speak because there are no male students in the classroom.

Based on the study above, the female students who have already been in the single-sex classroom, have high confidence, convey strong enthusiasm and maintain eye contact well in speaking English. The classroom condition which homogenous with all students are female influence them become freer to speak up in English and more enjoy learning to speak because there are no male students in the classroom. According to the teacher, she stated that:

"The implementation of single-sex classroom management is significant for helping students the o develop their English speaking skill especially in three items such as eye contact, enthusiasm, and confidence. With this separated between female students and male students, they are more focus on the learning process." (Int. February 11, 2015)

However, there are some of them sometimes have less confidence, enthusiasm and eye contact and it caused by their vocabulary, grammar, and pronunciation. According to the teacher, she said that:

"Sometimes, some of my students less confidence, enthusiasm and eye contact caused by the lack of vocabulary, the grammar, and pronunciation." (Int. February 11, 2015)

The possible reason is big ashamed because they have to join in the singlesex classroom with are not male students. This condition is true based on some theories explained in the previous chapter. The researcher thinks that learning English speaking in the single-sex classroom is very suitable for female students. While, the result classroom observation, female students who have already been in the single-sex classroom, have high confidence, convey strong enthusiasm and maintain eye contact well in speaking English. It is true that the factor of female students ${ }^{\text {ee }}$ higher outcome in this type of classroom is inhibition. In the single-sex classroom, they are freer to speak English in front of their friends, and they are very confident. Those conditions bring them into higher English speaking skill achievement. The researcher explains that male and female students have own need, style and classroom situation need in learning. Female students in the class can deliver their messages and ideas.

Moreover, finally, the researcher analyzed that the eleventh year's students of the single-sex classroom management at SMA IT Wahdah Islamiyah Makassar, Makassar, Indonesia have mastered the English speaking skills regarding eye contact, enthusiasm, and confidence in which the researcher in a single-sex classroom has done the criteria. Based on the study above, the female students who have already been in the single-sex classroom, have high confidence, convey strong enthusiasm and maintain eye contact well in speaking English. The classroom condition which homogenous with all students are female influence them become freer to speak up in English and more enjoy learning to speak because there are no male students in the classroom. According to the teacher, she stated that: 
"The implementation of single-sex classroom management is significant for helping students to develop their English speaking skill especially in three items such as eye contact, enthusiasm, and confidence. With this separated between female students and male students, they are more focus on the learning process." (Int. February 11, 2015)

However, there are some of them sometimes have less confidence, enthusiasm and eye contact and it caused by their vocabulary, grammar, and pronunciation. According to the teacher, she said that:

"Sometimes, some of my students less confidence, enthusiasm and eye contact caused by the lack of vocabulary, grammar, and pronunciation." (Int. February 11, 2015)

The possible reason is big ashamed because they have to join in the singlesex classroom with are not male students. This condition is true based on some theories explained in the previous chapter. The researcher thinks that learning English speaking in the single-sex classroom is very suitable for female students. While, the result classroom observation, female students who have already been in the single-sex classroom, have high confidence, convey strong enthusiasm and maintain eye contact well in speaking English. It is true that the factor of female studentse higher outcome in this type of classroom is inhibition. In the single-sex classroom, they are freer to speak English in front of their friends, and they are very confident. Those conditions bring them into higher English speaking skill achievement. Male and female students have own need, style and classroom situation need in learning. Female students in the class can deliver their messages and ideas. Moreover, finally, the researcher analyzed that the eleventh year's students of the single-sex classroom management at SMA IT Wahdah Islamiyah Makassar, Makassar, Indonesia have mastered the English speaking skills regarding eye contact, enthusiasm, and confidence in which the researcher in a single-sex classroom has done the criteria.

\section{CONCLUSION}

This study revealed that female students reported their experience that they were more willing to speak in their single-sex class. Means that, the key is female students' inhibition which can be eliminated in the single-sex classroom and it makes them easier to speak English (Kylberg \& Wulff, 2009). Furthermore, as explained before that there are several ways can be done in improving students' speaking skill achievement facilitate the students to speak, give more time and chance to deliver their ideas, elicit as frequently as possible in order the students are interested in speaking up or other activities. Moreover, those ways are done in single-sex classroom management by the teacher (Herron, 2014) and those ways help the students to have mastered in English speaking skill.

This suggestion is addressed for those who have an interest in the issue of students in single-sex classroom management in mastering students ${ }^{\text {ee }}$ English speaking skills regarding eye contact, confidence, and enthusiasm. The result of the data analysis, the researcher, states that several factors influence singlesex classroom management help students in mastering English speaking skill. Because of that, the researcher expects the teacher apply this single-sex 
classroom management in teaching and learning English speaking skill to reach the best achievement of the students. Also, the researcher finds out several explanations related to the female students in mastering their confidence, eye contact, and enthusiasm. Beside the single-sex classroom implemented there, they should encourage their vocabulary, more practice in producing pronunciation, and learn more about the structure or grammar of the sentence. Moreover, those will help them to be mastered in English speaking skill. Eventually, for further research, the future research could use the same type of classroom management but investigate female students and also male students in the single-sex and also mixed classroom.

\section{REFERENCE}

Creswell, J. W., \& Creswell, J. D. (2017). Research design: Qualitative, quantitative, and mixed methods approaches. Sage publications.

Demers, S., \& Bennett, C. (2007). Single-sex classrooms.

Doris, A., O’Neill, D., \& Sweetman, O. (2013). Gender, single-sex schooling and maths achievement. Economics of Education Review, 35, 104-119.

Herron, A. (2014). Single-sex classrooms. The Education Digest, 79(9), 49.

Hughes, T. A. (2006). The Advantages of Single-Sex Education. Online Submission, 23(2).

Jackson, C. (2002). Can single-sex classes in co-educational schools enhance the learning experiences of girls and/or boys? An exploration of pupils' perceptions. British Educational Research Journal, 28(1), 37-48.

Kylberg, J., \& Wulff, A. (2009). English in single-sex classrooms. English teachers' considerations when selecting texts for single-sex classes.

Malik, R. (2013). Differential Effects of Single Sex versus Coed Education on the Personality Development of Primary School Students. Pakistan Journal of Social Sciences (PJSS), 33(1).

Morse, S. (1998). Separated by sex: A critical look at single-sex education for girls. Amer Assn of Univ Women.

Pahlke, E., Hyde, J. S., \& Allison, C. M. (2014). The effects of single-sex compared with coeducational schooling on students' performance and attitudes: A metaanalysis. Psychological Bulletin, 140(4), 1042.

Parker, L. H., \& Rennie, L. J. (2002). Teachers' implementation of gender-inclusive instructional strategies in single-sex and mixed-sex science classrooms. International Journal of Science Education, 24(9), 881-897.

Patak, A. A., Nur, H., Said, H., \& Yaumi, M. (2014). Proceedings of The 1st Academic Symposium on Integrating Knowledge (The 1st ASIK): Integrating Knowledge with Science and Religion. Ibnu Sina Institute for Fundamental Science Studies. Retrieved from https://books.google.co.id/books?id=vhdYBQAAQBAJ

Smyth, E. (2010). Single-sex education: what does research tell us? Revue Française de Pédagogie. Recherches En Éducation, (171), 47-58.

Thomas, R. M. (2003). Blending qualitative and quantitative research methods in theses and dissertations. Corwin Press.

Thompson, T., \& Ungerleider, C. (2004). Single-sex schooling: Final report. Canadian Centre for Knowledge Mobilisation: Waterloo, Ontario. 0.

Trickett, E. J., Trickett, P. K., Castro, J. J., \& Schaffner, P. (1982). The independent school experience: Aspects of the normative environments of single-sex and coed secondary schools. Journal of Educational Psychology, 74(3), 374. 